\title{
Non-powder gunshot injury of the parapharyngeal space
}

\author{
Raden Ayu Hardianti Saputri, Annika Famiasti, Nur Akbar Aroeman, \\ Agung Dinasti Permana, Sinta Sari Ratunanda \\ Department of Otorhinolaryngology Head and Neck Surgery,
}

Faculty of Medicine, Padjadjaran University / Dr. Hasan Sadikin General Hospital, Bandung

\begin{abstract}
Background: Non-powder firearm is a weapon which used compressed air or CO2 gas to propel lead or steel ball pellets. Trauma caused by non-powder firearm has the potential for significant morbidity and mortality. Head and neck wounds account for $13.8 \%-30 \%$ of all non-powder firearm injuries. Bullets from gunshots often nest in the parapharyngeal space. Purpose: To present a case of non-powder firearm trauma in parapharyngeal space and its management. Case Report: A 13 years-old boy came with nonpowder firearm trauma on the left cheek and bleeding from the left nostril. Upon physical examination there was a vulnus sclopetorum sized $0.5 \mathrm{x} 0.5 \mathrm{~cm}$ without active bleeding in the left zygoma area. Three dimensional CTscan showed a hyperdense metal lesion in the left parapharyngeal space with $42.6 \mathrm{~cm}$ distance from penetrating site to the bullet location. The bullet was then extracted with transparotid approach surgery guided by C-arm imaging. Clinical Question: How is the management of trauma from a non-powder gunshot in the parapharyngeal space? Review method: Literature search through Pubmed, Cochrane Library, and Wiley using non-powder firearm injury in parapharyngeal space and its management as keywords. Result: The search obtained 11 articles. Based on inclusion and exclusion criteria, one article was found relevant with the topic i.e. one case report of non-powder firearm injury in parapharyngeal space and its surgical management. Conclusion: The safe procedure for retrieving bullets from the parapharyngeal space is in the form of surgery with the help of C-arm imaging to pinpoint the bullet's location and to prevent further complication.
\end{abstract}

Keywords: non-powder firearm, gunshot injury, parapharynx space, C-arm

\begin{abstract}
ABSTRAK
Latar belakang: Senapan angin merupakan senjata yang menggunakan tenaga penggerak berjenis gas CO2 untuk melontarkan peluru. Trauma akibat senapan angin dapat berpotensi fatal. Sebanyak 13,8-30\% luka tembak senapan angin terjadi pada daerah kepala dan leher. Salah satu ruang leher yang kerap menjadi tempat bersarangnya peluru adalah ruang parafaring. Tujuan: Melaporkan kasus dan penanganan trauma tembak senapan angin pada parafaring. Laporan kasus: Anak laki-laki berusia 13 tahun dengan riwayat tertembak senapan angin di pipi kiri dan perdarahan dari hidung kiri. Pada pemeriksaan fisis didapatkan vulnus sklopetorum berukuran 0,5 0 0,5 cm tanpa perdarahan aktif di area zigoma kiri. Hasil CT scan 3D didapatkan lesi hiperdens dengan densitas metal pada parafaring kiri, berjarak 42,6 mm dari luka. Benda asing peluru kemudian diekstraksi melalui tindakan operatif menggunakan pendekatan transparotid dengan bantuan C-Arm. Pertanyaan klinis: Bagaimana penatalaksanaan trauma tembak senapan angin pada ruang parafaring? Telaah literatur: Penelusuran literatur melalui Pubmed, Cochrane Library, dan Wiley menggunakan kata kunci luka tembak senapan angin pada ruang parafaring dan penatalaksanaannya. Ditemukan 11 artikel, dan pemilihan artikel berdasarkan kriteria inklusi dan eksklusi, terdapat satu penelitian yang relevan. Hasil: Didapat satu laporan kasus tentang luka tembak senapan angin di ruang parafaring dengan tindakan bedah sebagai penanganannya. Kesimpulan: Tatalaksana pengambilan peluru yang aman adalah dengan pendekatan pembedahan dengan bantuan C-Arm untuk mencegah komplikasi lebih lanjut.
\end{abstract}

Kata kunci: senapan angin, luka tembak, trauma, ruang parapfaring, C-arm 
Correspondence address: dr. Annika Famiasti. Department of Otorhinolaryngology Head and Neck Surgery, Faculty of Medicine, Padjadjaran University/Dr. Hasan Sadikin General Hospital, Bandung. Email: afamiasti@gmail.com

\section{INTRODUCTION}

Non-powder firearm is a weapon which uses compressed air or $\mathrm{CO} 2$ gas to propel lead or steel ball pellets sized 4.5 millimeter in diameter. The force of impact of a projectile upon tissue contact is mainly determined by muzzle velocity (MV). The upper limits of the $\mathrm{MV}$ of a non-powder gun are ranging between 150-900 feet/second. Non-powder gun (NPG) has the potential to cause serious injury and it could be life threatening. ${ }^{1}$ The impact caused by NPG wounds is influenced by the site of entry and nesting of the projectile, organs that damaged by the projectile, and the ballistic factor which affects the direction of the kinetic energy caused by the impact of the bullets. ${ }^{2,3}$

The incidence of gunshot trauma is less common in countries without conflict, however, trauma from the NPG is not uncommon. Although the trauma and complications of firearms are widely known, trauma due to NPG is rarely reported and is not handled properly, especially in children. ${ }^{4,5}$

Veenstra et al. ${ }^{4}$ stated that $18.8 \%$ of gunshot wounds in children happened due to NPG and $68 \%$ of them were accidental.

Head and neck trauma due to gunshot wound injuries has a serious impact and could be fatal. Gunshot injury in the head and neck area accounted for $8 \%$ of deaths in gunshot wounds. $^{2}$

Although trauma and complications from firearms are widely known, trauma from the non-powder firearm is often underreported and not handled properly, particularly in children. ${ }^{5,6}$

Gunshot wounds caused by non-powder firearm often occur in the head and neck area. Head and neck injury related to nonpowder firearm shot reached up to $14 \%-20 \%$ of all gunshot injuries. ${ }^{1}$ One of the spaces in the neck where bullets often nest is the parapharynx space. The parapharynx space, also called the pharyngomaxillary space, or the lateral pharyngeal space, which is part of the deep neck spaces, is an important area, because it related to all major spaces in the neck and carotid space. ${ }^{7}$ Gunshot wounds in the parapharynx space are also potentially dangerous due to the presence of vital anatomical structures that are close to each other, such as the carotid artery, internal jugular vein, and also some important nerves such as cranial nerves VII, IX, X, XI, and XII. ${ }^{8,9}$

This study reported one case of nonpowder firearm gunshot wound in pharapharyngeal space and its management at the Dr. Hasan Sadikin General Hospital, Bandung.

\section{CASE REPORT}

A 13 years-old boy came to Dr. Hasan Sadikin General Hospital emergency unit with complaints of NPG wound in the left cheek and bleeding from the left nose. The complaints were accompanied by pain when opening the mouth and chewing. He was accidentally shot by his friend while hunting birds, in a short distance $( \pm 50 \mathrm{~cm})$ between rifle and face.

From the physical examination, the patient was fully alert, hemodynamic state was normal. Otorhinolaryngological, head and neck examination revealed blood clot on the left nostril, and no active bleeding from both nostrils. The patient had difficulty opening his mouth with interdental opening only $1 \mathrm{~cm}$, and had a vulnus sclopetorum sized 
$0.5 \times 0.5 \mathrm{~cm}$ in the left zygomatic area without active bleeding. There were no abnormalities of the ear, throat, head and neck, and no neurological disturbances.

AP lateral skull X-ray which was performed at Siloam Hospital showed radiopaque lesion in the left parapharyngeal area. Temporal CT Scan performed at
Dr. Hasan Sadikin Hospital showed a hiperdense lesion with metal density in the left parapharyngeal space, involving the left lateral and medial pterygoid muscles. There were fractures of the anterior and lateral walls of the left maxillary sinus, and there were hematosinus in the left maxillary and left ethmoidal sinuses.

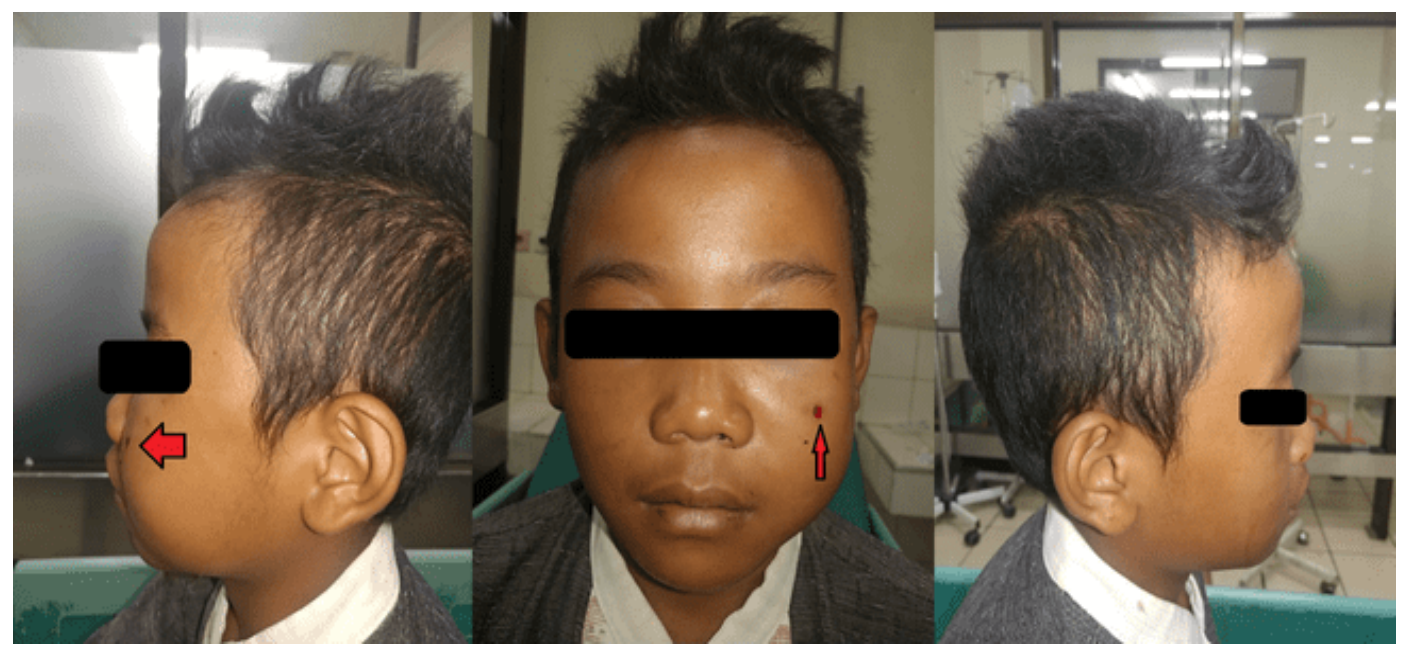

Figure 1. Before surgery

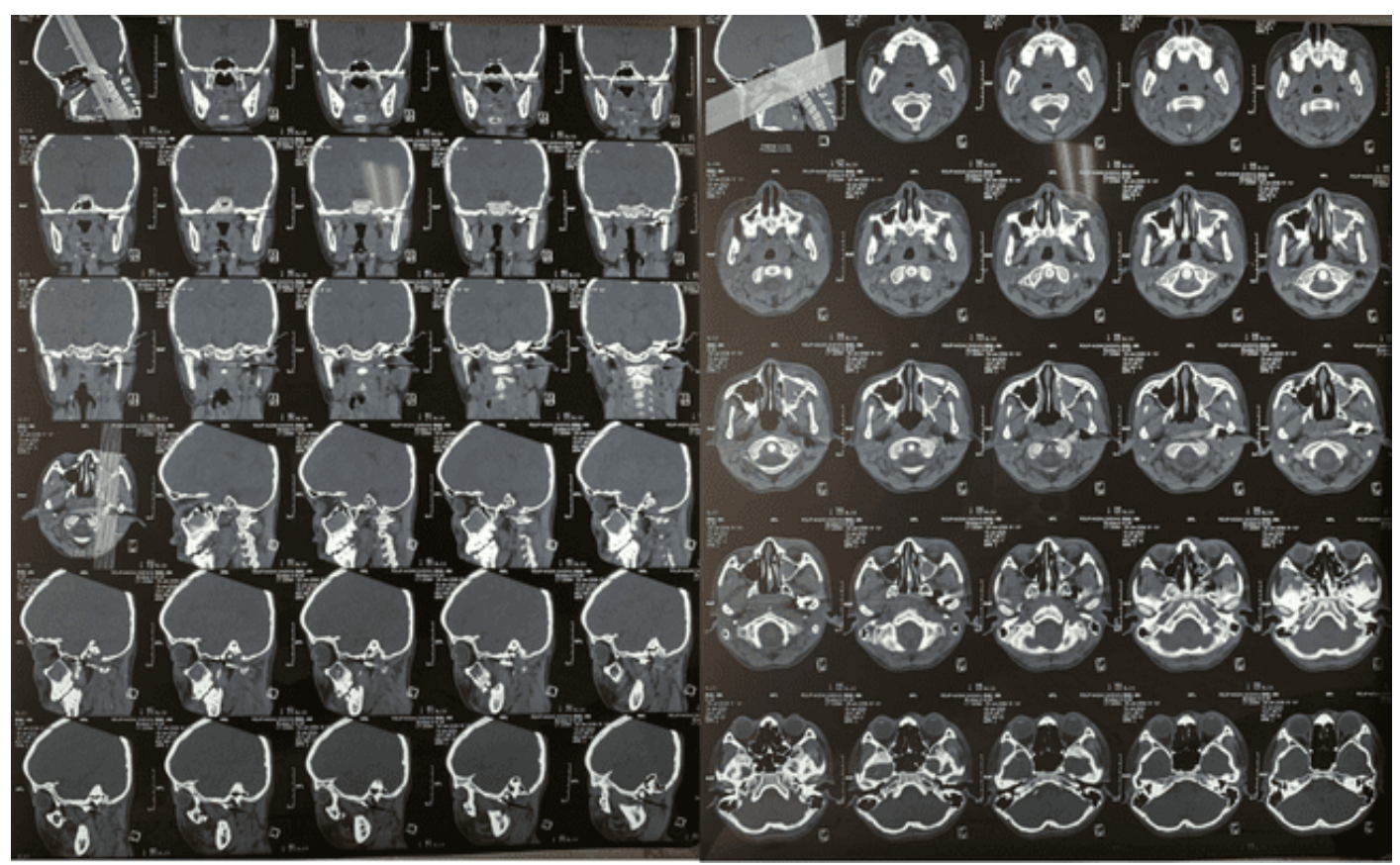

Figure 2. Temporal CT Scan revealed hyperdense metal lesion in the left parapharyngeal space 
The patient was then referred to Dr. Hasan Sadikin General Hospital and underwent facial CT Scan examination with 3-dimension reconstruction. The result showed there was a hyperdense metal lesion in the left parapharyngeal space with a distance of approximately $42.6 \mathrm{~mm}$ from the wound on the cheek to the projectile. This suggested that the bullet entered the cheek through the the anterior wall of left maxillary antrum, and went through into the parapharyngeal space. The patient was then planned to undergo surgery to extract the bullet from the parapharyngeal space.

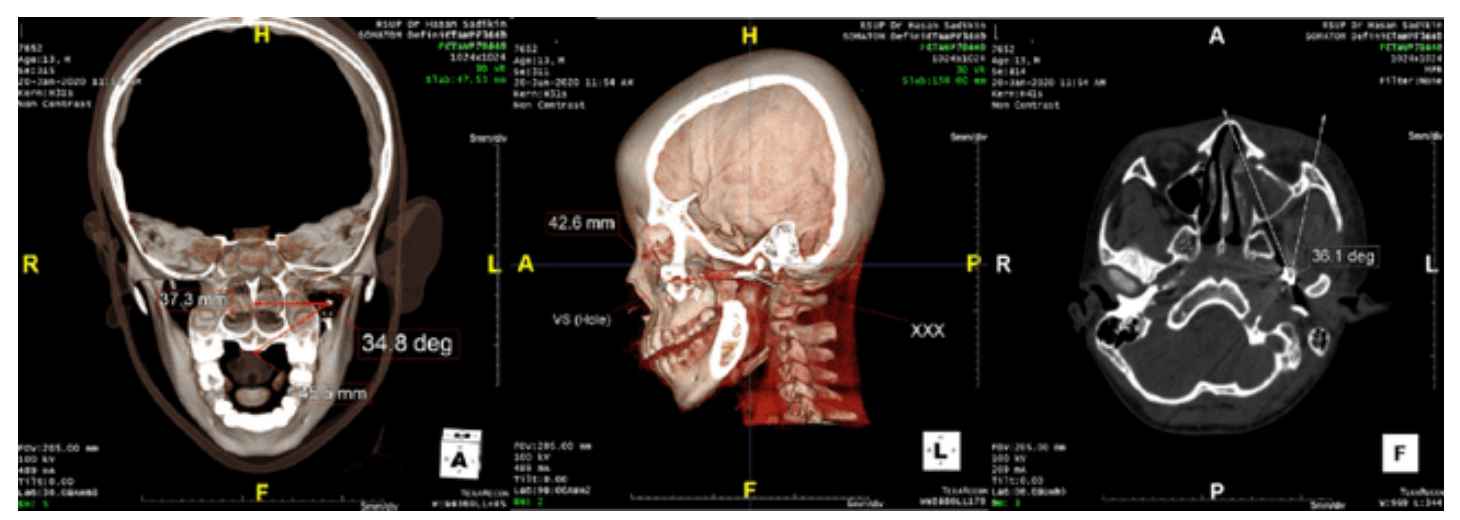

Figure 3. 3D CTscan. Hyperdense metal lesion in left parapharyngeal space

The patient was then prepared for a foreign body extraction surgery with transparotid approach on the left side of the face with $\mathrm{C}$-arm guiding under general anesthesia. The patient's head was turned to the right, so the left side of patient's face was confronted to the image intensifier of the $\mathrm{C}$-arm. The $\mathrm{C}$-arm was positioned zero degree oblique towards the left side of the patient's face. The bullet was found in the parapharyngeal space superpositioned to the left mandibular ramus, without injuring the internal jugular vein and carotid artery. The bullet was then carefully extracted, and the wound closed with a primary suture, finally a drain was placed.

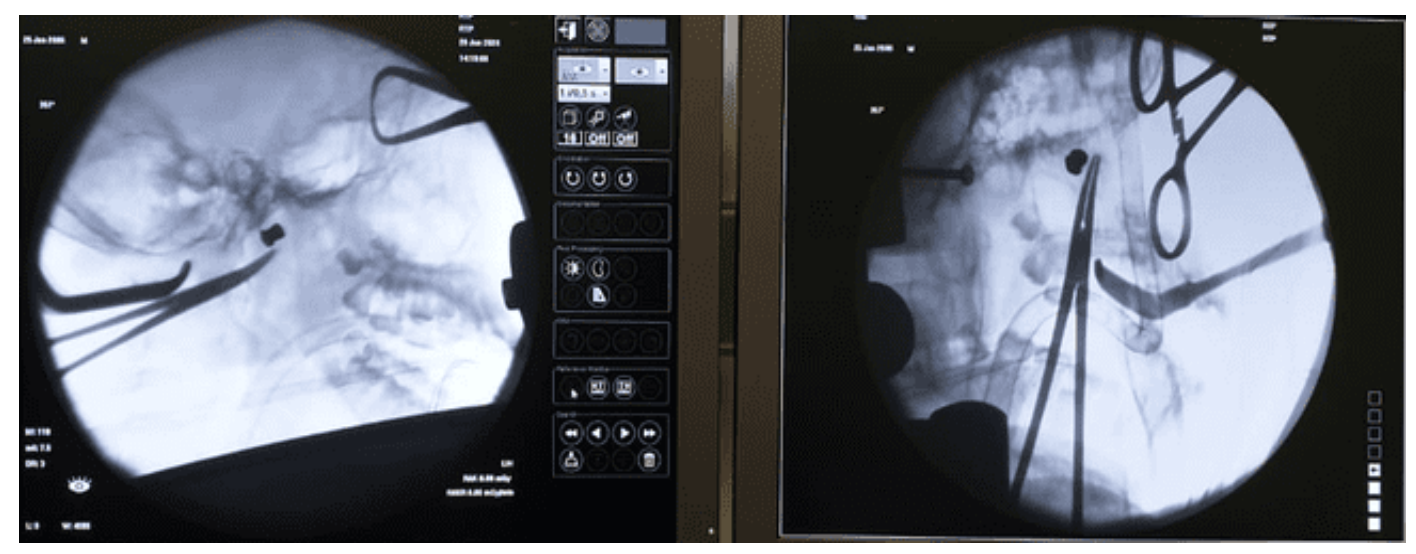

Figure 4. Location of the bullet from anteroposterior $\mathrm{C}$-Arm imaging during surgery 
Non-powder gunshot injury of the parapharyngeal space

Three days post-surgery the drain was removed and the wound suture was carefully tended. The patient was discharged four days post-surgery with prescription of Cefixime 2 x $100 \mathrm{mg}$, Ibuprofen syrup $3 \times 1.5$ teaspoon, and Methyl prednisolone $3 \times 8 \mathrm{mg}$ for three days. One week post-surgery the patient came to the Larynx-Pharynx Division clinic at Hasan Sadikin General Hospital without any complaints of pain or active bleeding. The wound sutures were then removed.

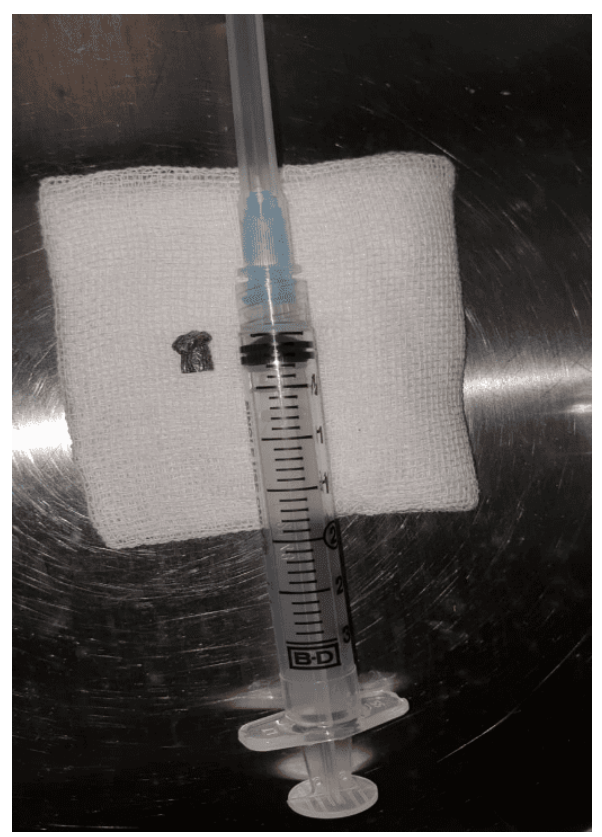

Figure 5. Bullet projectile extracted from the patient

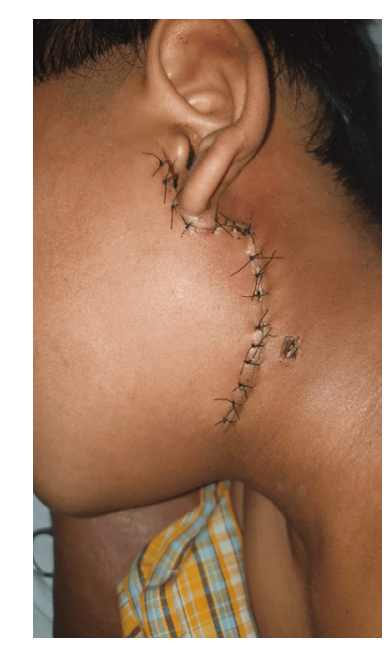

Figure 6. Postoperative wound

\section{CLINICAL QUESTION}

How is the management of trauma from a non-powder gunshot in the parapharygeal space?

\section{REVIEW METHOD}

Literature search through Pubmed, Cochrane Library, and Wiley using "gunshoot", AND "nonpowder", AND "air gun", AND "pharapharyngeal space", AND "head and neck", AND "trauma", AND "C-arm" as the keywords. The literature search yielded 9 journals in Pubmed, no journal in the Cochrane Library and 2 journals in Wiley.

Then a literature selection was carried out using the following inclusion criteria: 1) air gun; 2) trauma; 3 ) parapharyngeal space; 4) C-arm. The exclusion criterion was firearm. One complete manuscript was available.

\section{RESULT}

Isaac et al. ${ }^{7}$ reported that half of the non-powder gun injuries occurred in children aged 5 to 14 years, with an average death rate was four persons each year, $24 \%$ of which involved trauma to the head and neck. The anatomical structures are complex and close together between the respiratory tracts, gastrointestinal tract, large blood vessels and several important nerves are important factors in the occurrence of complications in trauma due to non-powder gun in children. ${ }^{7,8}$

Decision to choose the treatment for head and neck trauma could be complex and difficult, requiring an in-depth analysis of the risks that could occur. Non-surgical management might be considered in the absence of neurovascular injury.

Isaac et al. ${ }^{7}$ also stated in their case report that surgical management was chosen to prevent the infectious complications that often occurred in the parapharyngeal space 
due to the presence of foreign bodies. The C-arm was used to help locating the bullet during surgery. The advantage of using mobile image intensifier ( $\mathrm{C}$-arm) during surgery was the ability to pinpoint the location of the bullet precisely.

\section{DISCUSSION}

According to Zaidi et al. ${ }^{10}$ the potential harm caused by trauma depends on the anatomic region involved, when the trauma occurred. Most of penetrative wounds to the neck are caused by stab and gunshot wounds. The gunshot wounds that occur in the head and neck area ranged between 13.8\% - 30\% of all gunshot wounds. ${ }^{6}$ While the rest of the body is protected by bone and connective tissue, the large vessels, the respiratory organs and nerves in the neck are not protected by dense bone and connective tissue, therefore with the same energy impact, injuries to the neck have a higher mortality rate. The mortality rate from non-powder gunshot wounds is about $5-10 \% .{ }^{10}$

The parapharyngeal space - historically referred to as pharyngomaxillary or lateral pharyngeal space - is commonly described as an inverted pyramid spanning the distance between the skull base and the greater cornu of the hyoid bone. ${ }^{9}$ The lateral border of the space, from posterior to anterior, are the deep lobe of the parotid gland and the ramus of the mandible covered with the medial pterygoid muscle, and more inferiorly by the fascia of the posterior belly of the digastric muscle. Medially it is bounded by the superior pharyngeal constrictor muscle, and adjoins the retropharyngeal space. Anteriorly, the space is limited by the pterygomandibular raphae and posteriorly by the prevertebral fascia, carotid sheath and retropharyngeal space. Traditionally, the space is divided into an anterior and posterior compartment divided by the styloid process and fascial condensation called the aponeurosis of
Zuckerkandl and Testut, joining the styloid process to the tensor veli palatine, referred to as the pre and post-styloid spaces. In this case, the bullet nested in the poststyloid space which contains the internal jugular vein, internal carotid artery, cranial nerves IX, X, XI and XII, sympathetic trunk and superior sympathetic ganglion, ascending pharyngeal artery and lymph nodes. ${ }^{9}$

In our patient, there were no signs and symptoms of trauma to vital structures, and the hemodynamic was stable. The bullet was most likely entered the parapharyngeal space through the left cheek to the left maxillary sinus, penetrating the sinus posterior wall, then nested in the parapharyngeal space. From the 3 dimensional CT Scan it could be determined that the bullet was lodged in the left parapharyngeal space, $42 \mathrm{~mm}$ from the left cheek. After a careful bullet removal surgery, the wound could be mended without significant problems.

The first assessment and management of maintaining airway patency and controlling bleeding in gunshot trauma patients is important. In patients with gunshot trauma, radiological examinations including X-rays, CT scan, and angiography should be performed to support successful retrieval of the bullets. ${ }^{11}$ One of the advantages of mobile $\mathrm{C}$-arm is its ability to move around the patient, achieving the optimum angle for high quality image. The use of a portable imaging system (C-arm) during the bullet removal surgery helps locate the bullet accurately. ${ }^{12}$ However, a major disadvantage of the $\mathrm{C}$-arm is the unavoidable radiation exposure of the surgical team from fluoroscopic projections in the operating room and the imaging is limited to only one plane at a time. ${ }^{11}$

It should be kept in mind that projectiles from firearms are not sterile, the heat generated by the discharge of the propellant as well as the friction between the bullet and barrel is not sufficient to sterilize the bullet. Contamination could occur from the 
bullet and also from skin flora and foreign bodies (clothing) carried into the wound. Historically, Streptococcal bacteremia was the most important cause of death on the battlefield in the pre-antibiotic era. Wounds in which the bullet traverses the aerodigestive tract or paranasal sinuses are at particular risk. Damaged tissue and vascular congestion leads to an ideal environment for bacterial growth. ${ }^{13}$

The most important objective of taking the bullet out by surgery assisted by $\mathrm{C}$-arm is to prevent further complications due to the effects of pressure from foreign bodies. ${ }^{14}$

\section{REFERENCE}

1. Freeman J.J., Bachier-Rodriguez M, Staszak J, Feliz A. A comparison between nonpowder gun and powder-gun injuries in a young pediatric population. Injury. 2017; 48(9): 1951-55

2. Can M, Yildirim N, Ataç, G. K. Dissecting firearm injury to the head and neck with non-linear bullet trajectory: A case report. Forensic Science International. 2010; 197(13): 13-17.

3. Y. Tan, S. Zhou, H. Jiang, Biomechanical changes in the head associated with penetrating injuries of the maxilla and mandible: an experimental investigation, J. Oral Maxillofac. Surg. 2002; 60: 552-56.

4. Veenstra M, Prasad J, Schaewe H, Donoghue L, Langenburg S. Nonpowder firearms cause significant pediatric injuries. J Trauma Acute Care Surg. 2015; 78(6): 1138-42.

5. Williams M, Ballard DH, DeLeonardis C. Pediatric unintentional firearm injuries: a Northwestern Louisiana trauma center analysis. Am Surg. 2015; 81: 653-54.

6. Dandu KV, Carniol ET, Sanghvi S, Baredes S, Eloy JA. A 10-year analysis of head and neck injuries involving nonpowder firearms. Otolaryngology-Head and Neck Surgery. 2017; 156(5): 853-56.

7. Isaac A, AlQudehy Z, El-Hakim H. Penetrating injury to the parapharynx space caused by a BB gun in pediatric patient. J. Pediatr. Surg. Case Rep. 2013; 1(2): 25-7.
8. Bora MK, Narwani S, Mishra P, Bhandari A. A bullet in the parapharynx space. Indian J Otolaryngol Head Neck Surg. 2002; 54(1):46-7.

9. Blumberg JM, Judson BL. Surgical management of parapharynx space infections. Operative Techniques in OtolaryngologyHead and Neck Surgery. 2014; 25 (3): 304-9

10. Zaidi H, Ahmad R. Penetrating neck trauma: a case for conservative approach. American J. Otolaryngol. 2011; 32(6): 591-96.

11. Offiah C, Hall E. Imaging assessment of penetrating injury of the neck and face. Insights Imaging. 2012; 3: 419-31.

12. Merzaa AM. Bullet removal from the infratemporal fossa. Ann. Maxillofac. Surg. 2016; 6(2): 292-96

13. Ramadan AB, Farhat S, Alwahedi OM. Bullet in the para pharyngeal space. Glob. $\mathrm{j}$. otolaryngol. 2017; 8(1).

14. Bayram A, Kaya A, Kalkan M, Özcan I, Mutlu C. An Unusual Bullet Trajectory. J. Craniofac. Surg. 2017; 28(7): 636-37. 